\title{
TWO THERAPEUTIC EXPERIMENTS ON STUBBORN PAIN IN SPINAL CORD LESIONS: COUPLING MELITRACEN-FLUPENTHIXOL AND THE TRANSCUTANEOUS NERVE STIMULATION
}

\author{
By DR A. HeILPORN \\ C.T.R.—Hôpital Brugmann, Brussels, Belgium
}

Abstract. A drug combination was used against sub-lesional pain with some good results. result.

Transcutaneous stimulation was used in three cases of pain in the roots without

Key words: Pain medical treatment; transcutaneous stimulation.

PAIN may be considered as a major complication of a medullary lesion only in a very low percentage of patients when the case of a post-traumatic patient is concerned. In our population, it represents not even 2 per cent of our patients. We accept as serious pain phenomena those which involve a notable limitation of independence and which blocks the possibilities of activity. We feel that the painful complaints which become evident only following a systematic interrogation or which can be diminished by simple attitudes or means without really impeding activity, are not susceptible to particular research and specific therapeutics.

In the semiology of the traumatic spinal lesion, we distinguish two types of pain which persist or develop after the stage of spinal shock: segmental irritation which localises itself in belts or in bands at the level of the lesion, and the sublesional pains, topographically very variable and often diffuse, localised in an anaesthetised region following the clinical investigation.

Whatever the medicinal therapeutic measures, we systematically prescribe to take the rehabilitation treatment again and involve the patient in a succession of obligatory activities such as occupational, diversive and functional. The attitude towards life must be modified, and it is necessary to de-dramatise the handicapping factor of the pain. Finally, it is necessary to research into the psychological and emotional factors susceptible to induce a morbid attitude which is not necessarily withdrawn into a painful pretext but which, more often, disturbs the will of the patient in his efforts to surmount an unpleasant phenomenon.

As with all services concerned with the treatment of paraplegics, our aim is to bring out those patients blocked by a real painful pathology. In this respect, we wish to bring the results obtained from two therapeutic tests: in the first place, an original drug combination and, secondly, a transcutaneous electrical stimulation. The first formula is indicated in the sub-lesional pain whereas the second is only evident in radicular pain.

\section{Material}

We are considering the cases of 12 patients who have finished their rehabilitation and who consult us specifically for the problem of pain; these being the principal handicap in their independence (Table I). The first thing to note is the abundance of the psycho-social component which affects this population. It is difficult to 
TABLE I

Paraplegics with pain syndrome

\begin{tabular}{|c|c|c|c|c|}
\hline Patients & Sex & $\begin{array}{l}\text { Segmental level } \\
\text { of lesion }\end{array}$ & Type of pain & Psychological aspects \\
\hline I & M & TI2 & $\mathrm{P}+\mathrm{R}$ & Dynamic \\
\hline 2 & M & $\mathrm{T} 8$ & $\mathrm{P}$ & Isolated \\
\hline 3 & M & TII & $\mathrm{P}+\mathrm{R}$ & Dependent-Passive \\
\hline 4 & M & $\mathrm{T}_{4}$ & $\mathbf{P}$ & Affective conflict \\
\hline 5 & M & $(\mathrm{LI})$ & $\mathrm{P}+\mathrm{R}$ & Isolated-Depression \\
\hline 6 & $\mathrm{M}$ & TI2 & $\mathrm{P}$ & Isolated-Ethylic \\
\hline 7 & M & $(\mathrm{T} I 2)$ & $P+R$ & Passive \\
\hline 8 & $\mathrm{M}$ & Tió & $P$ & Suicide tendency \\
\hline 9 & $\mathrm{~F}$ & TII & $P$ & Suicide neurosis \\
\hline Io & $\mathrm{M}$ & T6 & $P$ & Passive \\
\hline I I & $\mathrm{M}$ & T9 & $\mathbf{P}$ & Isolated \\
\hline 12 & $\mathrm{~F}$ & Tio & $\mathbf{R}$ & Affective conflict \\
\hline
\end{tabular}

$\mathrm{P}=$ Sub-lesional pain. $\mathrm{R}=$ Segmental irritation.

define if the pain expression is partly determined by psychological factors or if the comportment is modified as a result of this difficulty. In any case, the current analgesics, non-opiated, have established themselves as being of little or of no use at all. The appreciation of the results is based, partly on the declarations of the patients and partly on our observation of their vitality and on their capacity for activity.

Eleven of these patients presented diffuse sub-lesional pain and were subjected to the combination of Melitracen-Flupenthixol. This dosage was chosen following the works of Noel et al. (1970) and, as a result of its success was used in other types of pain. The doses recognised as effective in the treatment of the pain are $3 \times 50 \mathrm{mg}$ of Melitracen and $3 \times \mathrm{I} \mathrm{mg}$ of Flupenthixol per day. It is important to note that our experiment as that made in other services (Put, I974) confirms the effectiveness of these therapeutic agents in numerous different pathologies at a time when research for an experimental confirmation was not regarded as conclusive (Pederson \& Fjalland, 1975).

Three of the patients were cases presenting true painful complication due to involvement of spinal roots, and were subjected to a therapeutic trial by transcutaneous nerve stimulation. Electrodes were placed on the cutaneous surface at the level of the painful region. A battery stimulator was used. The batteries of small dimensions permit the passage between the two electrodes of square waves, the frequency and amplitude of which can be varied.

\section{Results}

Amongst the II patients subjected to this drug combination five found themselves distinctly better, four manifested a new vitality in their activities and three stated a certain improvement where we could objectively conclude any modification in their behaviour. Three did not respond to the medication and did not improve in any way to its use (Table II). Complications happened in three cases of which, one included ocular problems and the other two, micturition difficulties. In each 
TABLE II

Melitracen-Flupenthixol applications

\begin{tabular}{|c|c|c|c|c|c|}
\hline Patients & Pain intensity & $\begin{array}{c}\text { Duration of } \\
\text { treatment }\end{array}$ & $\begin{array}{l}\text { Beginning } \\
\text { action }\end{array}$ & Result & Side effects \\
\hline I & ++ & $3 \mathrm{~W}$ & I W & + & ++ \\
\hline 2 & ++ & $2 M$ & $2 W$ & + & \\
\hline 3 & +++ & $3 \mathrm{~W}$ & - & o & \\
\hline 4 & +++ & $3 M$ & $3 \mathrm{D}$ & \pm & + \\
\hline 5 & ++ & $2 M$ & I W & \pm & \\
\hline 6 & +++ & $2 \mathrm{~W}$ & - & $\overline{0}$ & ++ \\
\hline 7 & +++ & $2 M$ & I $M$ & \pm & \\
\hline 8 & +++ & $3 M$ & $3 \mathrm{D}$ & $\bar{t}$ & \\
\hline 9 & ++ & I $M$ & I W & + & \\
\hline IO & ++ & $2 M$ & - & 0 & \\
\hline II & +++ & $2 \mathrm{~W}$ & I W & + & ++ \\
\hline
\end{tabular}

Pain: ++ high intensity, limits independence; +++ prevents activity.

Duration: $\mathrm{W}=$ week, $\mathrm{M}=$ month, $\mathrm{D}=$ day.

\section{TABLE III}

Patients treated by transcutaneous stimulation

\begin{tabular}{ccc}
\hline Patients & Pain intensity & Result \\
\hline 3 & +++ & \pm \\
7 & +++ & 0 \\
I2 & ++ & \pm \\
\hline
\end{tabular}

of these three cases, the treatment had to be interrupted. The patients concerned were subjected to alternative neurotropic tests: Lorazepam, Imipramine, Levromepromazine, generally without results. Three patients out of I I, maintained the treatment long enough to regain a dynamic attitude and a real independence. One of these patients is still under medication. The other two have gradually stopped the medication.

Three patients with root pain were subjected to transcutaneous electrostimulation tests. Two patients out of three revealed a temporary modification in their painful sensation: the gradual obliteration of pain as well as thelocal dysaesthesia made for an electrical sensation in the same region this being equally unpleasant. They did not show signs following the cessation of the stimulation of a disappearance or prolonged diminution of the painful phenomenon. One patient out of three felt no modification whatsoever even by application of unpleasant intensities on numerous regions.

The two patients who felt a transformation of the painful phenomenon were not convinced by the treatment and pointed out that it hindered their independence. 


\section{Discussion}

In the very different and relatively exceptional pathology with which we are occupied, three positive results out of the I 2 may be obtained. The use of the psychotropic medication in the treatment of the pain, is not new (Beroud \& Dangoumau, I969; Merskey \& Hester, I972; Nick \& Contamin, I969). The therapeutic failures however, are extremely frequent and we have not yet met any success with the other drugs of the same type. This drug combination may be badly tolerated and must be used under medical supervision, especially in the case of possible sphincter troubles.

The precutaneous nerve stimulation has been proposed in the past few years and declared efficacious in diverse painful pathologies, especially in the peripheral regions. It deserved therefore to be tried in those of our patients with radicular pain. The three tests that we carried out in our establishment are not conclusive. In addition to its lack of efficacy, this method appears to hinder the patient by the encumbrance created by the installation. Finally, considering its limits, we did not pursue the use of this technique and proposed the recourse of the implantation of electrodes on the nerve tracts, this being a method which offers the advantage of limiting the awkwardness of the installation.

\section{Conclusions}

We feel that in the case of stubborn pain and, more particularly, in the case of those which are without a precise topography and are located sub-lesionally, the drug combination of Melitracen-Flupenthixol deserves to be given a chance.

The transcutaneous stimulation in root pain is unconvincing. In any case, our therapeutic attitude is based before anything else is done on the stimulation of the individual, physically and psychologically, by a functional rehabilitation treatment both complete and dynamic.

Melitracen: anti-depressive tricyclic, thymo-analeptic. Commercial names : Dixeran in Belgium, Austria, Switzerland, Trausabun in Germany and Holland.

Flupenthixol: derivation of Thiaxanthène, neoroleptic. Commercialised under the name Fluanxol in Benelux and the United Kingdom and under the name Emergil in France.

\section{SUMMARY}

Following a brief analysis of the painful complications encountered in paraplegics, a description is given of their neurological and psychological context. Two therapeutic experiments are presented, their use depending on the preferred treatment. A criticism of the results obtained is given: we were considering 12 cases of stubborn pains.

The drug combination of Melitracen-Flupenthixol appears efficacious in allaying pains below the lesion. Since this drug is not always tolerated, however, its field of application is restricted.

The transcutaneous nerve stimulation was tested by three patients and did not provide sedation for pains in the roots.

Whatever the therapeutic used against pain, the patient is subjected to a dynamic rehabilitation treatment. 


\section{RÉSUMÉ}

Aprés une brève analyse des complications douloureses rencontrées chez le paraplégique, une description en est faite en rapport avec leur contexte neurologique et psychologique.

Deux expériences thérapeutiques sont présentées en fonction de leurs indications préférentielles. Une critique des résultats obtenus en est donnée sur base de I 2 cas de douleurs tenaces.

L'association médicamenteuse 'Melitracen-Flupenthixol' s'est révélée efficace dans les douleurs sous-lésionelles. Cette médication n'est pas toujours tolérée ce qui en réduit le champ d'application.

La stimulation nerveuse transcutanée a été essayée chez 3 patients et n'offre pas de sédation des douleurs radiculaires.

Quelle que soit la thérapeutique choisie puor le phénomène douloureux, le patient est soumis à un traitement dynamique de réadaption.

\section{ZUSAMMENFASSUNG}

Nach einer kurzen Analyse der schmerzhaften Komplikationen, die bei Querschnittsgelähmten auftreten ein Gutachten mit der Beschreibung des Kontextes neurologisch und psychologische ist gemacht. Zwei Experimente therapeutisch sind dergestellt. Eine Kritik der erhaltenen Resultate, auf Grundlage von I2 Fällen der Hartnäckigsten Schmerzen wird gemacht. Die Kombiniering von 'melitracen-flupenthixol' erweist sich als wirksam bei Schmerzen der Verletzungen, die Verabreichnung der Medikamente wird nicht immer gut vertragen was das Feld der Verwendung verkleinert. Die transkulane elektrische Stimulation wurde subkutan bei 3 Patienten versucht aber zeigten kein Verminderung der Schmerzen by spinalen Wurzeln Affektionen.

Welch auch immer Therapeutik für das schmerzhafte Phänomen angewandt wird der Kranke muss sich einer dynamischen Behandlung der Readaption unterwerfen.

\section{REFERENCES}

Beraud, C. \& Dangoumau, S. (1969). Les medications antalgiques. Gaz. Méd. de Fr., 76, $2701-2925$.

Houssa, P. \& Noel, G. (1957). Les douleurs des paraplégiques. Bruxelles Médical, 37, 1995-2002.

MERKSEY, H. \& Hester, R. A. (I972). The treatment of chronic pain with psychotropic drugs. Postgraduate Medical fournal, 48, 594-598.

Nick, J. \& Contamin, F. (I969). Traitement de douleurs rebelles observées en milieu neurologique par l'association de médicaments anti-dépresseurs et neuroleptiques. Vie Médicale, 35, 4285-4291.

Noel, G., Piraux, A., Magnery, P. \& Meyers, C. (1970). Considérations préliminaires sur l'association Melitracen-Flupenthixol dans les algies rebelles. Bull Soc. Clin. Hôp. Charl., XXI, I47-I52.

Pederson, V. \& FJalland, B. (1975). Analgesic Effect of Combinations of Flupenthixol (N 7009) and Melitracen (N 7001) in mice and rabbits. Special Report, Department of Pharmacology. H. Lundbeck and Co., Copenhagen.

Put, T. R. (1974). Traitement des douleurs rebelles à l'aide du Flupenthixol et du Melitracen. Ars Medici, 29, I4OI-I4I3. 